\title{
Gender and knowledge production in institutions of higher learning: an African context
}

\author{
Promise Zvavahera, Mercy Dikito-Wachtmeister, \\ Sheppard Pasipanodya, Natasha Salome Mwenda \\ and George Okumu Achar
}

\begin{abstract}
This study focuses on the factors that contribute to the low production of knowledge by women compared to men in terms of the number of research outputs and recommends ways of narrowing the gap. Literature suggests that the social construction of gender and the consequent different gender roles and responsibilities of women or men inform this social phenomenon. This is because the social construction of what it means to be a man and a woman subordinates and confines women to the private sphere and men to the public sphere. These patriarchal discourses and practices of private and public spaces shape women's roles in society, including their participation in the production of knowledge. A cross-sectional survey in Zimbabwe, Malawi, and Kenya shows that gender indeed impacts knowledge production. The study found that women had limited access to research grants, limited exposure to higher institutions of learning, and also had limited mentorship by men as there were few women who could play the mentorship role. The study recommends full support for women researchers by providing funding, creating mentoring units, commercialising research outputs, engaging in advocacy, and crafting and implementing affirmative polices that support their work. This has a net effect of increasing the participation of women in knowledge production and in the development of national and global economies.
\end{abstract}

Keywords: Knowledge production, gender, research outputs, patriarchy.

(C) The author(s) 2021. This is an open access article licensed under a Creative Commons Attribution-NonCommercial-NoDerivs 4.0 Unported License 


\section{Introduction}

Even though Africa is the second-largest continent after Asia, it contributes only between $1 \%$ and $2 \%$ of all research outputs (Hassan 2001, Sachs 2005, World Bank 2005). The development of knowledge for sustainable development has been one of Africa's pursuits since 2013. Africa's Agenda 2063 goal 6 states that the continent is striving for 'An Africa where development is people-driven, unleashing the potential of both women and youths' (African Union Commission 2015: 34). In spite of these pursuits, not much knowledge has been generated on gender gaps and how to address these gaps so as to attain sustainable development. Women continue to contribute less research output compared to their male counterparts. For Africa to achieve the goals of Vision 2063, there is, firstly, a need to nurture women's development potential from an early stage, because they face social-cultural constraints as they grow up and come up the educational systems. As they constitute half of the world's population, girls and women represent a resource waiting to be tapped for the socio-economic development of the world. The United Nations (UN) recognises gender equality as a fundamental human right, as enshrined in the Universal Declaration of Human Rights adopted by the General Assembly in 1948 (UN 2015: 15). This is also in line with the Sustainable Development Goals numbers 4 and 5 which speak to Quality Education and Gender Equality, respectively. Secondly, women's ability to pursue education is constrained by lack of financial resources and support, as many parents in Africa have for a long time preferred to educate a boy child and not a girl child who will get married and not benefit the family. Women are often forced to depend on their male counterparts in decision-making from an early stage in the educational sector where they are often subordinated to men. This early subordination also means they face the possibility of gender-based violence by men from an early age. It has been observed that men in Sub-Saharan Africa reinforce their positions by abusing women through sexual and violent means (Stewart 2006). Africa therefore faces a huge challenge in implementing Agenda 2063 goals and the Sustainable Development Goals. Africa needs to scale-up the participation of women in knowledge production so that they can equally contribute to the socio-economic development of the continent and beyond. Therefore, this study sought to investigate the causes of gender gaps in knowledge production in institutions of higher learning with reference to Kenya, Malawi, and Zimbabwe. 


\section{Literature review}

This study is informed by feminist literature. It seeks to understand how to attain gender equality between women and men in knowledge production in institutions of higher education globally as well as on the African continent with a specific focus on three countries: Kenya, Zimbabwe, and Malawi.

\section{Theoretical framework}

The study draws from Feminist Theory because of its focus on gender and unequal power relations between women and men and hence patriarchy. Feminist theories were developed around 1794 (Kolmar \& Bartowski 2005). Feminist Theory further amplifies the conflict approach to scrutinise gender roles and inequalities and how this has perpetuated the superiority of men against women. It also informs the dynamics of men's dominance and women's subordination and how they are both reproduced through patriarchy. However, Minangkabau (2004) argues against this conflict model of gender relations and suggests that women and men in Indonesia and other parts of the world cooperate rather than compete at work. It is also noted that in the United States of America (USA), no job is regarded as feminine, as all people are equal regardless of gender and sex (Sanday 2004).

Feminism argues that patriarchy is instituted through structures that support men to positions of power, access, and control of income and other resources. This is supported by Pop (2016) who concluded that the patriarchal system in Romania continues to create gender disparities between women and men and that this has led to the notion of male supremacy over women and also contributes to unequal power relations between women and men. It is further argued that the reproduction of women's inferior roles in society makes it difficult to change the position of women, as it contributes to the perception of men as assertive and aggressive whilst women are perceived to be emotional, charming, and gentle. He also notes that there are gender gaps between women and men in terms of labour and wages, education, and access to resources, among other things. As an example, the author notes that, even though $60 \%$ of the university graduates in Romania were women, women constitute only $20 \%$ in the formal employment sector.

Gender disparities in higher education institutions (HEIs) is a global phenomenon (Davidson \& Burke 2004, Airini et al. 2011). Morley (2005) affirms that very little is being done to promote the participation of women in knowledge production in institutions of higher learning globally. Knowledge production involves researching, practising, creating, analysing, and recording significant information that is used to 
solve current and future challenges facing the world (Nketiah 2019). Some of the challenges that women researchers face pertain to lack of support from their universities and peers (Fathima et al. 2020). In this study, social exclusion refers to deprivation of research opportunities, lack of mentorship, limited chances of promotion, and limited chances to attend international conferences. The extent of social exclusion is well expressed by Fahmy and Young (2017), who note that most articles published in the Journal of Criminology and Criminal Justice are dominated by male writers. Men also want to co-author and publish with fellow men, and this leaves women with no mentors and so they end up as solitary publishers (Fisher et al. 1998: 36). Traditionally, women also do not get support from their male counterparts or their employing institutions (Chen et al. 2006, Rice et al. 2007, Cohn et al. 2014). Since the Me Too movement, editors have been receiving a lot of criticism for publishing issues with mostly male authors. This negatively weighs on women, as scholarly work is critical for tenure and promotion in universities. Even though most countries have attained gender equality in primary education, a significant gender gap still exists at higher levels of education.

Even though there has been a general increase in the number of women who are enrolling for undergraduate and postgraduate programmes globally, they still have limited access to senior positions, as result of their subordinate role in society (O'Connor et al. 2015). Since women are expected to play their traditional gender roles in the family, it becomes difficult to balance work and family life. Due to women's gender roles in the family and society, they are stigmatised and not taken seriously in institutions of higher learning globally. Prozesky and Mouton (2019) argue that women and men face different challenges in their careers globally. Globally, women are mostly constrained by discrimination, funding, and mentorship. Papadópulos and Radakovich (2005) note that, because the space in higher education has traditionally been the preserve of men, this has made men excel and be integrated into society easily, while women are left behind in inferior traditional roles. Literature also suggests that there are few female researchers who register for $\mathrm{PhD}$ and masters programmes globally. This reduces the number of women who get employed and eventually get promoted to positions of authority and decision-making (Sax et al. 2002, Rice et al. 2007, Snell et al. 2009).

In terms of women and men's fields of study, men dominate in hard sciences while women dominate in the social sciences (Prozesky \& Mouton 2019). This suggests gender stereotyping since there are areas that are perceived to be dominated and ringfenced by men and difficult for women to penetrate and participate in. Funding also tends to favour hard sciences and also clearly highlights men's domination of hard sciences as opposed to women's domination in humanities and the social sciences. 
Gender inequalities in African universities can be traced back to the colonial era when African male students were enrolled to serve the interests of the white elite while women looked after the family (Mama \& Barnes 2007). Ronning (2000) notes that there is power imbalance in academia and proposes the democratisation of institutions of higher learning globally. Guzura (2012) suggests that women's limited participation in knowledge production should be viewed from a colonial context and this is further reinforced by patriarchy. In this regard, men have power in the areas of moral authority, political leadership, control of property, and social privileges. This has led to under-representation of women in institutions of higher learning in Africa and beyond. Even though women have to some extent been role models in areas of research and leadership in their institutions (Nketiah 2019), African women need to break the barriers associated with knowledge production processes in institutions of higher learning.

In Zimbabwe, women are still are under-represented in positions of leadership in institutions of higher learning, though this is thirty-nine years after independence (Choruma 2019). Even though Zimbabwe made great strides in universalising education after independence, this has not completely addressed gender disparities. In Zimbabwe, harmful social norms and patriarchal practices create gender inequalities leading to the exclusion of women in leadership. Women in institutions of higher learning have been subjected to various forms of discrimination (Munando 2017). A study in Zimbabwe found that gender stereotypes constrained women from advancing to positions of leadership and this resulted in lack of confidence and low self-esteem (Chabaya et al. 2009). Women's role in the family is also a major constraint as it supersedes that at the workplace. More men occupy senior academic and administrative positions compared to women in Zimbabwe. Garwe (2015) found that, even though there is a legal framework to promote women, there is lack of political will to deal with gender-based violence in schools and institutions of higher learning by the government and this has cascaded into other sectors of the economy. She also notes that funders have withdrawn funding because the country is deemed an economic risk as a result of non-compliance with the agreed-upon rules on the use of funds.

Table 1 shows enrolments at universties in Zimbabwe by sex. Enrolments for women are higher at lower levels, but there are bottlenecks at postgraduate level. This is shown in Table 2, where no females completed their PhD studies in 2019. Numbers for female students start dropping at masters' programmes. This could be part of the gender educational trends that shape gender disparities in knowledge production in Zimbabwe.

In Kenya, women are under-represented in universities and there are very few of them in positions of authority (Odhiambo 2011). Only four vice-chancellors out of 
Table 1. Enrolment at universities by sex of students, 2019.

\begin{tabular}{|c|c|c|c|c|}
\hline & Male & Female & Total & $\begin{array}{l}\% \text { Share } \\
\text { of women }\end{array}$ \\
\hline Africa University & 1,161 & 1,380 & 2,541 & 54.31 \\
\hline Arrupe Jesuit University & 91 & 7 & 98 & 7.14 \\
\hline Bindura University of Science Education & 2,703 & 2,973 & 5,676 & 52.38 \\
\hline Catholic University in Zimbabwe & 1,277 & 1,521 & 2,798 & 54.36 \\
\hline Chinhoyi University of Technology & 5,267 & 4,742 & 10,009 & 47.38 \\
\hline Great Zimbabwe University & 5,615 & 9,104 & 14,719 & 61.85 \\
\hline Gwanda State University & 187 & 59 & 246 & 23.98 \\
\hline Harare Institute of Technology & 1,107 & 716 & 1,823 & 39.28 \\
\hline Lupane State University & 1,226 & 1,847 & 3,073 & 60.10 \\
\hline Manicaland State University of Applied Sciences & 417 & 171 & 588 & 29.08 \\
\hline \multicolumn{5}{|l|}{ Maronera University of Agricultural Sciences and } \\
\hline Technology & 120 & 73 & 193 & 37.82 \\
\hline Midlands State University & 10,874 & 11,004 & 21,878 & 50.30 \\
\hline National University of Science and Technology & 4,925 & 3,920 & 8,845 & 44.32 \\
\hline Reformed Church University & 183 & 435 & 618 & 70.39 \\
\hline Solusi University & 675 & 771 & 1,446 & 53.32 \\
\hline University of Zimbabwe & 8,293 & 9,130 & 17,423 & 52.40 \\
\hline Women's University in Africa & 653 & 2,530 & 3,183 & 79.48 \\
\hline Zimbabwe Ezekiel Guti University & 64 & 985 & 1,049 & 93.90 \\
\hline Zimbabwe National Defense University & 25 & 12 & 37 & 32.43 \\
\hline Zimbabwe Open University & 6,672 & 8,769 & 15,441 & 56.79 \\
\hline Total & 51,535 & 60,149 & 111,684 & 53.86 \\
\hline
\end{tabular}

Source: Ministry of Higher and Tertiary Education, Innovation, Science and Technology Development (2017).

Table 2. Distribution of population by highest level of education completed, in Zimbabwe in 2019.

\begin{tabular}{lrrrrrr}
\hline & \multicolumn{3}{c}{ Percent } & \multicolumn{3}{c}{ Total } \\
\cline { 2 - 7 } Level completed & Women & Men & Total & Women & Men & Total \\
\hline None & 59.6 & 40.4 & 100 & 616,502 & 417,944 & $1,034,446$ \\
ECE & 50.6 & 49.4 & 100 & 433,763 & 423,684 & 857,447 \\
Primary & 53.1 & 46.9 & 100 & $2,956,740$ & $2,616,188$ & $5,572,928$ \\
Vocational, National Foundation Certificate & 51.1 & 48.9 & 100 & 9,999 & 9,554 & 19,553 \\
Lower Secondary & 52.6 & 47.4 & 100 & $2,493,028$ & $2,246,422$ & $4,739,450$ \\
Upper Secondary & 40.8 & 59.2 & 100 & 98,197 & 142,601 & 240,798 \\
Vocational Certificate & 48.7 & 51.3 & 100 & 46,941 & 49,380 & 96,321 \\
Vocational/Apprenticeship/Teacher Training & 59.7 & 40.3 & 100 & 79,354 & 53,512 & 132,866 \\
Tertiary-Short Cycle & 51.7 & 48.3 & 100 & 70,325 & 65,674 & 135,999 \\
Tertiary-Higher National Diploma/Bachelor/ & & & & & & \\
$\quad$ Bachelor Honours & 47.7 & 52.3 & 100 & 98,749 & 108,242 & 206,991 \\
Tertiary-Masters/Doctoral Medical Courses & 45.1 & 54.9 & 100 & 19,127 & 23,303 & 42,430 \\
Doctorate & 0.0 & 100.0 & 100 & 0 & 998 & 998 \\
Not known & 42.5 & 57.5 & 100 & 755 & 1,021 & 1,776 \\
Level not known & 0.0 & 100.0 & 100 & 0 & 347 & 347 \\
Total & $\mathbf{5 2 . 9}$ & $\mathbf{4 7 . 1}$ & $\mathbf{1 0 0}$ & $\mathbf{6 , 9 2 3 , 4 8 3}$ & $\mathbf{6 , 1 5 8 , 8 7 0}$ & $\mathbf{1 3 , 0 8 2 , 3 5 3}$ \\
\hline Soure: Ming
\end{tabular}

Source: Ministry of Primary and Secondary Education (2018). 
Table 3. Enrolment in public and private universities by gender and academic level (2016/2017).

\begin{tabular}{lrrrrrr}
\hline Enrolment & \multicolumn{2}{c}{ Public universities } & \multicolumn{2}{c}{ Private universities } & \multicolumn{2}{c}{ Total enrolment } \\
\hline Programme & Male & Female & Male & Female & Male & Female \\
\hline PhD & 5,449 & 2,923 & 698 & 507 & 6,147 & 3,430 \\
Masters & 27,952 & 20,815 & 5,037 & 4,417 & 32,989 & 25,232 \\
Bachelors & 233,882 & 167,045 & 39,969 & 37,522 & 273,851 & 204,567 \\
PGD & 491 & 399 & 129 & 81 & 620 & 480 \\
Total & $\mathbf{2 6 7 , 7 7 4}$ & $\mathbf{1 9 1 , 1 8 2}$ & $\mathbf{4 5 , 8 3 3}$ & $\mathbf{4 2 , 5 2 7}$ & $\mathbf{3 1 3 , 6 0 7}$ & $\mathbf{2 3 3 , 7 0 9}$ \\
\hline
\end{tabular}

Source: Commission for University Education (2018).

sixty-two at the time of the study were female. It is also important to note that, even though women researchers are under-represented globally, Kenya was found to be far less representative (Morley 2010). Akala (2019) avers that, even though there are progressive policies in Kenya on equality and equity in higher education, gender inequalities still persist. This has resulted in Kenyan women being relegated to the peripheries of power for decades. This is attributed to lack of opportunities and inferior education for women. This has affected the number of women who become researchers in institutions of higher learning and take up positions of authority. Limited enrolment is one of the many factors that contribute to women's limited occupation of leadership positions (NACOSTI 2014). It is observed that at all levels (bachelors, postgraduate diploma, masters, and $\mathrm{PhD}$ ) there were more male students than female students across all the academic levels, as shown in Table 3.

In Malawi, there is little documented information on gender and research in higher institutions of learning. However, statistics show that only around $6 \%$ of girls proceed to high school, meaning that those who progress to university are even fewer, leading to their under-representation in all sectors (Commission for University Education 2018). Gender-based violence on women in Malawi is reported to be perpetuated at primary, secondary, and university levels (Bisika et al. 2009). Literature gathered on Zimbabwe, Kenya, and Malawi notes that women have not been successful in reaching senior positions in academia as a result of gender discrimination.

The following section outlines the objectives of the study and methodology that was used.

\section{Research objectives}

\section{Main objective}

To investigate the causes of the gender gaps in knowledge production in institutions of higher learning in Zimbabwe, Kenya, and Malawi. 


\section{Specific objectives}

1. To analyse the levels of research outputs by sex in institutions of higher learning;

2. To identify practices and discourses affecting women in the production of knowledge in institutions of higher learning;

3. To analyse gender-related challenges affecting the production of knowledge in institutions of higher learning;

4. In light of the study's findings, to make recommendations to governments, institutions of higher learning, and researchers across Africa and beyond on how participation in the production of knowledge by women can be enhanced.

\section{Methodology}

A case study approach was taken focusing on institutions of higher learning in Zimbabwe, Malawi, and Kenya. The rationale for choosing the three countries was for comparison purposes to examine context-specific data from each country and to draw conclusions. The study was carried out from April 2020 to June 2020. Questionnaires were distributed electronically to both private and public institutions of higher learning in the three countries. The survey asked a mixture of closed and open questions. The open questions offered the respondents the opportunity to provide further comments. Eleven questions were formulated from the objectives of the study (Table 4). The objective was not to get high response rates but to involve individuals who represented the population of interest. In this study, the population was researchers in institutions of higher learning, both female and male. In the context of this study, institutions of higher learning refers to universities and colleges offering degrees. Purposive sampling was applied, targeting individuals who met the following criteria:

1. more than five years' research and teaching experience in an institution of higher learning;

2. a degree in any discipline; and

3. appreciation of gender-related issues.

The findings of this study can be generalised by inference, since challenges in the three countries were found to be similar, even though they varied in magnitude. Data was presented and analysed following the sequence of the objectives. 
Table 4. The following research questions were developed to address the objectives of this study. Responses were requested to provide further comments on specific questions.

\begin{tabular}{ll}
\hline 1. & Gender: $\quad$ male $\quad$ female $\square$ \\
2. & Age group \\
& $18-30 \square$ \\
3. & Title
\end{tabular}

\section{Findings and discussion}

This section presents and discusses the findings of the study in relation to the literature. Table 5 shows the response rates by country, where Malawi had the highest response rate followed by Zimbabwe and Kenya, respectively. The response rate for this study was $37 \%$, which is plausible since the acceptable response rate for online surveys is $2 \%$. The response rate in the three countries could have been affected by the restrictions caused by the COVID-19 pandemic. Some of the intended respondents 
Table 5. Responses by country by sex.

\begin{tabular}{lrrrr}
\hline Country & $\begin{array}{r}\text { Questionnaires } \\
\text { administered }\end{array}$ & $\begin{array}{r}\text { Male } \\
\text { responses (\%) }\end{array}$ & $\begin{array}{r}\text { Female } \\
\text { responses (\%) }\end{array}$ & $\begin{array}{r}\text { Responses rate } \\
\text { as percentage (\%) }\end{array}$ \\
\hline Kenya & 50 & 14 & 10 & 24 \\
Malawi & 50 & 34 & 16 & 50 \\
Zimbabwe & 50 & 28 & 10 & 38 \\
Total & 150 & 25 & 12 & 37 \\
\hline
\end{tabular}

Source: authors.

could have had challenges related to internet accessibility and connectivity, which they could only access when they were at their workplaces. In a normal environment, the response rate could have been higher.

What can be drawn from the three countries is that there were more male respondents than female respondents, showing a gap in gender. This could imply that there were more males employed in the institutions of higher learning compared to females. This could be an indication of the gender inequalities that still exist in institutions of higher learning in the three countries and beyond. This is to some extent confirmation of the belief of Feminist Theory that patriarchy means that men continue to overshadow women in institutions of higher learning.

\section{Age group and gender distribution}

Figure 1 demonstrates the distribution of respondents' age groups, with overall dominance of both males and females in the $31-40$ age group (25\% for males and $21 \%$ for females). There were more male respondents $(11 \%)$ who were more than 50 yearsold compared to females $(7 \%)$.

Most of the respondents were youthful and so they still had time to contribute to the socio-economic development of their countries and beyond through research, provided they got the necessary support from their employers and peers. In view of this, there is a need to support this young generation of male and female researchers so that they can realise their full potential. This still productive age group is supported by Africa's Agenda 2063, which is calling for their full participation in developing their economies through knowledge production (African Union Commission 2015).

\section{Level of education}

Figure 2 demonstrates the respondents' levels of education, which is particularly centred on masters' degrees with male respondents dominating both the masters and $\mathrm{PhD/doctorate} \mathrm{levels.} \mathrm{It} \mathrm{was} \mathrm{noted} \mathrm{that} \mathrm{those} \mathrm{who} \mathrm{were} \mathrm{in} \mathrm{the} 41-50$ age group or the 


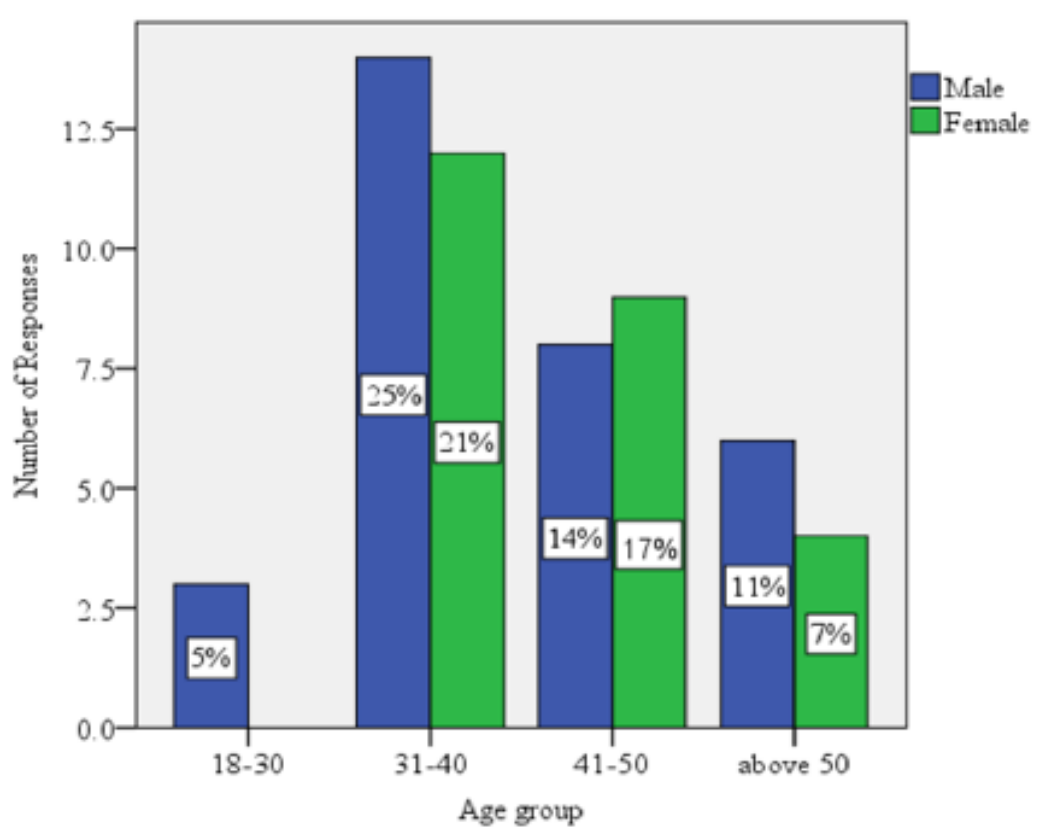

Figure 1. Gender distribution.

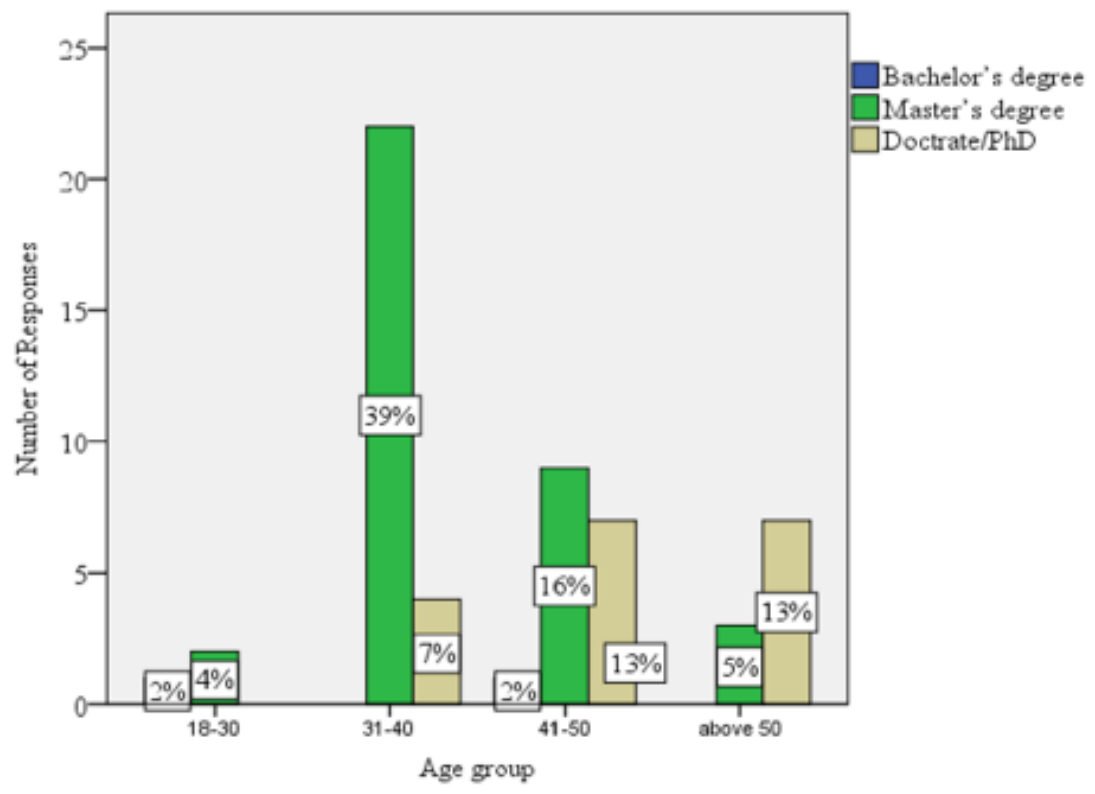

Figure 2. Level of education. 
50 and above age group had the highest number of $\mathrm{PhDs}$ for both females and males, standing at $26 \%$. Those in the age group 31-40 had the highest number of masters' degrees $(64 \%)$.

This could mean that the chances of acquiring $\mathrm{PhD} /$ doctorate degrees for those in the 30-40 age group were still high, considering their youth. It is also clear from a comparison of Figures 1 and 2 that there were more male respondents with PhDs compared to their female counterparts and this could also explain the disparities between genders in terms of opportunities and access to higher education and positions of authority. There may be various reasons for the gender and age difference in PhDs. Even though various African universities have in recent years made a conscious effort to increase the number of staff with PhDs and have offered them opportunities to acquire one and international donors have offered support for staff to acquire $\mathrm{PhDs}$, it is possible that in the selection of staff for PhD support, gender played a role. The findings of this study confirm the persistence of feminism and patriarchy in institutions of higher learning, as alluded to by Guzura (2012) in study that was carried out in Zimbabwe. This leads to women's limited participation in knowledge production. In this regard, men have power in the areas of moral authority, political leadership, control of property, and social privileges. This has led to under-representation of women in institutions of higher learning in Africa and beyond

\section{How gender-related challenges are affecting researchers}

This section presents and discusses gender-related challenges affecting researchers.

\section{Gender-based violence}

On gender-based violence, $75 \%$ of female respondents indicated that they were affected by gender-based violence and $18 \%$ of male respondents reported the same, whilst $7 \%$ remained neutral. The forms of violence that were mentioned by the respondents were sexual harassment, verbal abuse, and bullying.

It is important to acknowledge that gender-based violence against women in and around educational settings is a global phenomenon, and this is supported by Feminist Theory and the findings of this study. This is also supported by Airini et al. (2011) and Davidson \& Burke (2004). Even though there are progressive policies in the countries under study, gender-based violence still persists. Rampant gender-based violence in institutions of higher learning could lead to deprivation of opportunities for female researchers. Patriarchy has led to an unequal power balance between females and males in institutions of higher learning and this could be leading to gender-based violence (Pop 2016). This could also be based on sexuality, gender identities, and sex. 
As long as there is a lack of political will to address gender-based violence through practical policy implementation, women will remain downtrodden. This is also supported by Munando (2017; see also Chabaya et al. 2009) who found that women in institutions of higher learning in Zimbabwe have been subjected to various forms of discrimination, such as gender stereotypes, thereby constraining them from advancing to positions of leadership which resulted in lack of confidence and low self-esteem. In order for governments and institutions of higher learning to achieve their goal of equality and equity in institutions of higher learning, they should observe the tenets of Africa's Vision 2063 and the Sustainable Development Goals numbers 4 and 5 which speak to quality education and gender equality. These advocate for the recognition and support of women researchers in contributing towards the development of their economies across the continent and beyond.

\section{Social and economic exclusion}

Women in all three countries were found to be affected the same way in socio-economic activities in their places of work. In this study, social exclusion refers to discrimination against women in participating in social programmes and activities as a result of gender, social identity, or sexuality. On the other hand, economic exclusion refers to the denial of resources to women that would allow them to grow professionally and assume positions of responsibility and power resulting in financial benefits. More female respondents $(67 \%)$ were socially and economically excluded compared to male respondents (25\%). Only eight ( $8 \%$ ) remained neutral. Only $2 \%$ of women researchers indicated that they had an opportunity to attend regional and international conferences and workshops. Female researchers in Kenya and Malawi also complained about heavy workloads to the extent that they had little time to engage in research. It was also noted that women researchers in Zimbabwe had equal workloads to their male counterparts, but still remained socially and economically excluded from most important projects and programmes.

Even though universities could be providing resources for research, it could be that gender is playing a part in their distribution. Gender could also be playing a part when it came to nominations of who should attend conferences or workshops that required funding and institutional support. This is seen to be perpetuating the patriarchal system which still has a strong grip in institutions of higher learning in the three countries, since very few women indicated that they had the opportunity to attend regional and international workshops and conferences. Since women were given inferior roles and heavier workloads, they had less chance to do private consultancy alongside their academic work, denying them extra income and recognition. This also included limited chances of getting funding or personal financial resources 
to attend regional and international conferences and workshops. Even though the issue of gender inequalities cannot be generalised in patriarchal societies, like the ones under study and beyond, men and women do not always benefit equally from economic resources. The subordination of women has even cascaded into the workplace where men are given preferential treatment. Traditionally, HEIs have been the preserve of men and this has perpetuated the reproduction of gender inequalities, leading to social and economic exclusion (Papadópulos \& Radakovich 2005). Patriarchal structures and ideologies, the discursive and material contexts of people's lives, and the extent to which women are emancipated or subordinated in their societies, influence whether development initiatives will differentially advantage women or men. These factors, however, are particularly difficult to assess in Africa since countries have different social and cultural backgrounds. Social exclusion was observed to be in the form of discrimination by ethnicity and gender in Kenya and this affected women's participation in knowledge production. In Zimbabwe and Malawi social exclusion was not related to ethnicity but to gender in general. This perception of women can also affect their access to research funding and mentorship by their male counterparts and superiors who make decisions on these matters. The findings of this study concur with those of Pop (2016) who found similar challenges among women in Romania, and was found to be the case in Zimbabwe, Malawi, and Kenya and possibly across Africa and beyond. It is perceived that patriarchy is the dominant socio-cultural regime throughout Africa and this finding is supported by Feminist Theory and the findings of this study. The limited participation of women in knowledge production could be because of their limited access to education and related resources. It is, therefore, critical for governments and institutions of higher learning to advocate for legislation and policies that empower women in education and their participation in socio-economic activities. The promotion of innovation and research outputs by women could advance their standing, enabling them to play critical roles in the economic development of their economies through their research outputs. This is because most progressive economies are a result of innovations which are a product of research. Depending on the nature of research outputs, some of them can be commercialised, leading to industrialisation and employment. This is how economies are grown, because research is used to find solutions to current and future problems. The socio-economic exclusion of women researchers in knowledge production also affects their participation in development.

\section{Gender discrimination}

Gender discrimination in this study refers to the treatment of people based on their gender, sex, or sexuality. Of the respondents who were women $84 \%$ were facing gender 
discrimination; $11 \%$ of male respondents were not affected by gender discrimination whilst $5 \%$ of male respondents remained neutral. Sexual harassment, implicit bias, and sexism were mentioned as forms of discrimination affecting women researchers. This was said to be mostly from their male counterparts who happened to be in positions of authority. However, in Malawi, it was noted that gender discrimination occurred at every level. Even junior male academic and administrative staff were found to be perpetrating gender discrimination against female employees. In Zimbabwe, even though it is practised, it was found to be silent. Female respondents indicated that such remarks and behaviours were damaging and retrogressive. This was reported to be negative and diminished confidence in women researchers. In Kenya gender discrimination was along the lines of ethnicity. Women researchers in Zimbabwe called for proportional representation in all positions of authority. It was also highlighted that the few women researchers were grooming other women to assume leadership positions.

The presence of high levels of gender discrimination in the three countries under study was worrisome. It calls for immediate action so that there is gender equality and equity. Implicit bias is a form of stereotyping concerning the perceived role of women, in this case their subordinate role in society (Odhiambo 2011). It could be that their male counterparts were soliciting for sexual favours when female researchers requested assistance with their research work. Gender discrimination was found to be an impediment to the participation of women in knowledge production in the countries under study. While this study is not global in nature as it was confined to Zimbabwe, Kenya, and Malawi, the findings concur with those of Airini et al. (2011) and Davidson and Burke (2004) that gender discrimination is a global phenomenon. Odhiambo (2011) also added his voice by indicating that women in Kenya were under-represented in institutions of higher learning to the extent that there were very few of them in positions of authority in academia. Morley (2005) affirms that very little was being done to promote the participation of women in institutions of higher learning in Africa and beyond. Gender discrimination can manifest in many forms: for instance, limited access to resources, opportunities, and assignment to inferior roles like teaching and supervising in undergraduate programmes. This can also lead to limited access to resources and mentorship. Gender discrimination is the worst impediment to the progress of female researchers in Africa and beyond.

\section{Exploitation}

Of female respondents $72 \%$ were being exploited in one way or another and $9 \%$ of male respondents reported the same, whilst $11 \%$ remained neutral. In this study, exploitation refers to the act of treating people unfairly or using resources in order to 
benefit an individual at the expense of another person. Women researchers indicated that they were given inferior roles in their departments, such as teaching and supervising bachelors' programmes and to a lesser extent masters' programmes. It was noted that only $2 \%$ women were supervising PhDs and 5\% were supervising masters' students and the larger chunk of $\mathrm{PhD}$ supervision was for men. When it came to resources, female researchers indicated that they were only given opportunities to attend local seminars and conferences, yet their male counterparts participated in international conferences. It was noted that research funds and other resources were controlled mostly by male researchers and they determined their allocation as well. It was found that some female respondents complained about heavy workloads, leaving them with little or no time to do research. This is also linked to economic and social exclusion whereby they had very few opportunities to be involved in research, access to research funds, or opportunities to be mentored. Since few of them were involved in research, this also affected their attendance at regional and international conferences.

The findings of this study are in agreement with those of Papadópulos and Radakovich (2005), who note that traditionally, space in higher education has been the preserve of men and this has propelled their successful integration into society, leaving women in their traditional roles of looking after the family and engaged in inferior roles. Ronning (2000) confirms this as he argues that the main issue is about power imbalance in academia, which is in favour of men as a result of the socialisation process. The democratisation of institutions of higher learning could alleviate the gender-related challenges that girls and women face with respect to educational attainment. Guzura (2012) suggests that the lesser participation of women in knowledge production should be viewed from a colonial context where opportunities were almost non-existent for women in Africa and other parts of the world before independence.

\section{Practices and discourses are affecting researchers}

Figure 3 depicts practices and discourses that are affecting researchers, particularly women. The study noted that there were cross-cutting issues affecting researchers in institutions of higher learning in the three countries. Women were found to be more affected because of their subordinate roles and their undervalued positions in society as a result of the patriarchal systems that are still prevalent in Africa and beyond. They were given heavier workloads compared to their male counterparts.

Women were also found to have limited freedom and participation in research, and this obviously affected their research outputs, reducing their chances of participating in the development of their economies. Limited access to research funding was 


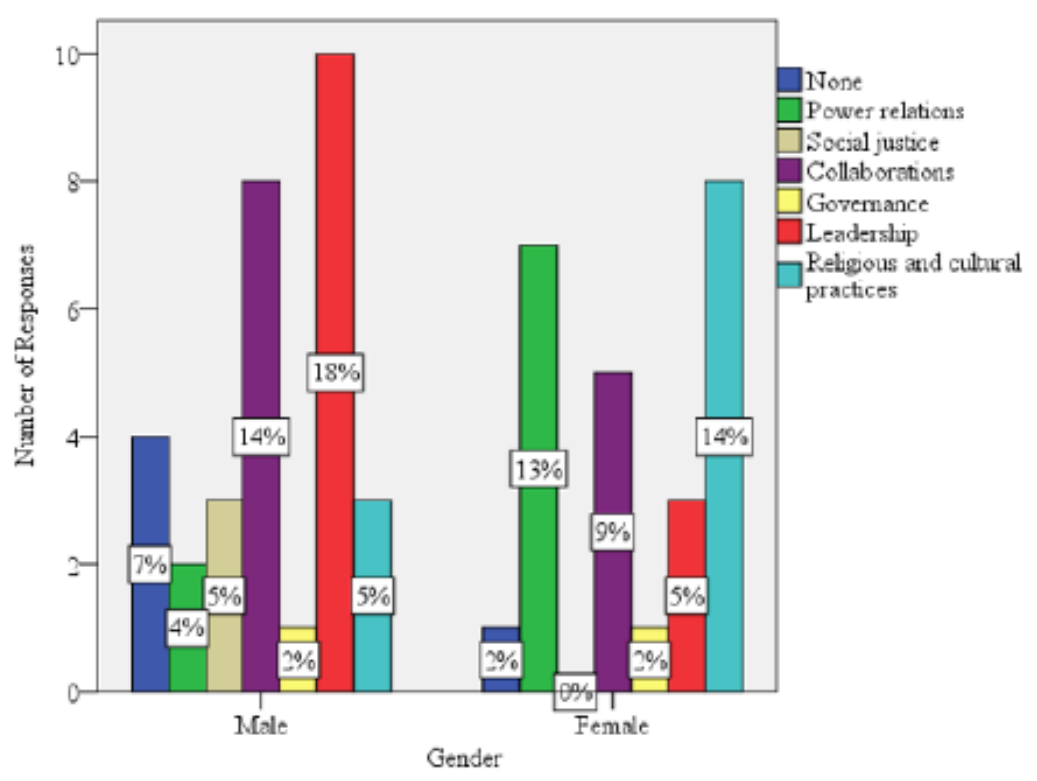

Figure 3. Practices and discouse affecting researchers.

found to be affecting their research outputs as well. It was noted that men made most decisions since they were in positions of power, yet women were involved in productive tasks that cater for the family. What strongly came out of Zimbabwe was that research was not rewarding at all and funding was virtually non-existent. In Malawi and Kenya it was noted that research funds were available for those who could produce good grant proposals. It could also be that women researchers were lacking in this area which was found to be male dominated. Most of the research that was being done by both male and female researchers was self-funded and this presented serious challenges. It was found that men would take decisions to spend part of their salary on research while women would perhaps regard their salary as part of the family income and not wish to spend that on research. It was noted that in Zimbabwe the government and institutions of higher learning were promoting girl children and women in STEM (science, technology, engineering, and mathematics). In Malawi and Kenya it was the survival of the fittest which left women exposed.

Gender inequality in higher education has manifested itself in areas of specialisation which are regarded as being for men or for women, leading them to particular careers. This could be as a result of societal and cultural factors resulting in the classification of careers and areas of study as female or male. Society holds the belief that boys do better in school than girls. In some cases, subjects could be assigned by gender identity and this could be perpetuating male dominance. This supports the proponents of 
Feminist Theory. In Zimbabwe patriarchy is still being practised in some parts of the country giving less space to women (Sanday 2002). The findings of this study are not in line with Africa's Agenda 2063 (African Union Commission 2015) which seeks to tap into the potential of women to aid Africa's development. This means that the African continent needs to do much more to promote female academics in the area of research, through funding and other initiatives.

Leadership was found to be affecting female respondents more (58\%) than male respondents $(5 \%)$. This was in terms of leadership roles and authority. Some of the respondents indicated that their male bosses asked for sexual favours in return for promotion or other rewards. Further to that, women were found to be most affected by religious and cultural practices $(67 \%)$. Of female respondents $63 \%$ were found to be affected by power relations compared to $4 \%$ of male respondents. However, it was noted that $9 \%$ of the respondents indicated that they were not affected in any way. Most female employees (78\%) indicated that their research outputs were not being used to develop their economies. This could be attributed to cultural beliefs in which women's work is not taken seriously.

It is a major concern that gender practices and discourses were not being taken seriously by different societies, as it was found to be affecting women researchers most. The findings of this study support the ideology of Feminist Theory whereby women's views and contributions are marginalised or silenced, since they are regarded as inferior. Gender norms are beliefs that are held based on gender differences. These are connected with power relations, gender roles, and standards that govern human behaviours and practices in a particular social context and at a particular time. This is about how men and women are expected to behave. What is important is to note that gender norms are hierarchical and create space in favour of men. This thinking has resulted in the subordination of women and still continues to do so, as evidenced by the findings of this study. Traditional gender roles emanating from the family home are a major impediment for the advancement of women researchers, since they inform their career paths. It is also clear that gender beliefs are shown in men's and women's short and long-term goals, social identities, and anticipated future social and economic roles. This can also affect both their occupational and educational choices. In order to achieve gender equality in institutions of education, there is a need to address these norms which are retrogressive to the development of women.

This can also be attributed to how gender norms, cultural values, ideas, and values shape institutions and the family. Men have strategically placed themselves in positions of authority and power and they continue to preserve that. The findings of this study concur with those of Fahmy and Young (2017) who notes that most articles published in the Journal of Criminology and Criminal Justice were dominated by male writers and there were a few collaborations with female researchers. This is an 
indication that women still trail behind in terms of knowledge production due to a number of challenges militating against them, which means they cannot equally contribute towards the socio-economic development of their countries. This is because of men's cultural and religious beliefs. This area becomes critical as it shows how gender norms and values shape institutions, including the family. In order to achieve gender equality, this means addressing these norms and values. This may call for policy interventions from governments and higher education institutions.

It is clear from the findings of this study that institutions of higher learning and governments in the three countries were not doing enough to address gender gaps in knowledge production by failing to fund research and support women researchers. They are also failing to address most of the issues affecting women researchers. Even though some female researchers had published some work, Prozesky and Mouton (2019) insist that gender gaps in knowledge production still persist.

\section{Types of research outputs}

Figure 4 shows the types of research outputs in which both male and female researchers were participating. It was noted that women researchers were doing equally well compared to their male counterparts in terms of publishing in refereed journals, standing at $22 \%$ each. However, it was found that most of these female researchers were partnering male researchers who in most cases proposed areas of research and provided funding. Men were doing well by publishing in conference proceedings $(17 \%) \mathrm{com}$ pared to female researchers (11\%), meaning that more male researchers attended and participated in international conferences compared to their female counterparts. What was encouraging was that women outpaced men in commissioned reports, presentations, and book chapters. Neither male nor female respondents had registered patents.

It should be noted that where women participated most it did not benefit them much because these formats are less prestigious than having an article published in a well-known refereed journal. No female researchers in this study had produced a book, whilst $1 \%$ of male researchers had done so. The findings of this study concur with those of Pop (2016) who found that women in Romania still constitute a small number in employment and in occupying positions of authority in academia. This is the case in Zimbabwe, Malawi, and Kenya and beyond, as evidenced by the research findings. Although there were some research outputs for women, there was no evidence as to how these were supporting economic development. 


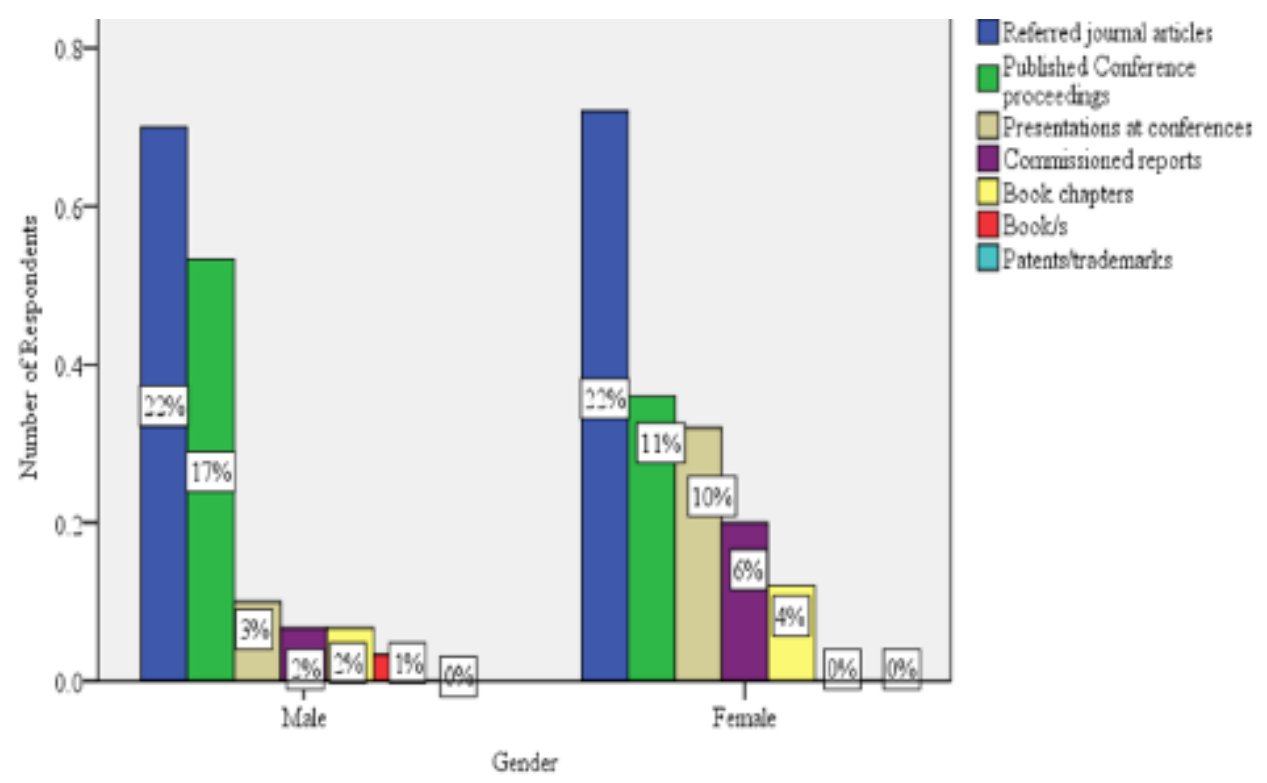

Figure 4. Research outputs by gender.

\section{Recommendations}

Since gender inequalities were found to be affecting female researchers more than their male counterparts, it is recommended that governments and institutions of higher learning enact and implement policies that advance the interests of female researchers. In terms of dealing with the challenges cited, creating communities of researchers for women is important. This could assist in sharpening their skills so that they can fully participate in research, leading to economic development. Supporting the work of female researchers through funding and mentorship is important. In order to address these gender gaps, there should be a shift to all-inclusive genderreceptive approaches that would move beyond simply enabling women's access to HEIs to issues affecting women's ability to fully participate and perform within these institutions. Since women are faced with a plethora of challenges, there is a need to make sure that they can participate equally in knowledge production. Women should be engaged in research that is directed at national development by creating value in order to remain competitive on the global market. These research outputs can also be used to inform government and institutional polices. Depending on the nature of the research, some of the outputs can be commercialised. In light of the findings of this study, this could be the opportunity to promote innovations from women so that development is fully realised. There is a need to conduct research on the relationship between gender and workforce productivity in institutions of higher learning. 


\section{Conclusion}

Female researchers in Kenya, Malawi, and Zimbabwe were found to be facing similar challenges, notably: lack of funding; gender discrimination; lack of mentorship for female researchers and lack of collaboration with male researchers. However, social and economic exclusions were also affecting female researchers more than their male counterparts and this was found to be affecting their participation in socio-economic development. Gender discrimination was found to be rooted in cultural beliefs, norms, and values in Zimbabwe, Kenya, and Malawi. In Malawi sexual harassment and gender discrimination were found to start at primary level and few female students progressed to secondary education, thereby affecting those who proceeded to university. Researchers in Kenya and Malawi complained about heavy workloads, yet in Zimbabwe workloads were found to be the same for both men and women. Zimbabwe had higher percentages of female students at undergraduate level, but the numbers dwindled at higher levels. For Malawi and Kenya, numbers were suppressed from the lowest levels. In Kenya, social and economic exclusion was arranged along the lines of ethnicity and this affected women's participation in knowledge production and economic development. In Zimbabwe and Malawi social and economic exclusion was not about ethnicity but about gender and sexism. It is important to acknowledge that patriarchy is the dominant socio-cultural regime in the three countries and beyond. Patriarchy was found to be deep-rooted in the three countries under the study. Whilst in Kenya and Malawi funding was available, in Zimbabwe it was difficult since traditional funders withdrew as a result of lack of accountability on the financial support provided in the past. What came strongly out of Zimbabwe was that research was not rewarding at all and funding was virtually non-existent. A few women researchers in Zimbabwe were also grooming and supporting upcoming female researchers. It can therefore be concluded that gender inequalities in institutions of higher learning have affected the participation of women researchers in knowledge production and their participation in economic development.

\section{References}

African Union Commission (2015), Agenda 2063: The Africa We Want. https://www.un.org/en/africa/osaa/pdf/au/agenda2063.pdf

Airini, C.S., Conner, L., McPherson, K., Midson, B. \& Wilson, C. (2011), 'Learning to be Leaders in Higher Education: What Helps or Hinders Women's Advancement as Leaders in Universities', Educational Management Administration \& Leadership, 39: 44-62. https://doi.org/10.1177/1741143210383896 
Akala, B. (2019), 'Gender Inequality in Education is Still an Issue in Kenya and South Africa'. https://theconversation.com/gender-inequality-in-education-is-still-an-issue-in-kenya-and-southafrica-125747.

Bisika, T., Ntata, P. \& Konyani, S. (2009), 'Gender-violence and Education in Malawi: A Study of Violence against Girls as an Obstruction to Universal Primary School Education', Journal of Gender Studies, 18(3): 287-94. https://doi.org/10.1080/09589230903057183

Chabaya, O., Rembe, S. \& Wadesango, N. (2009), 'The Persistence of Gender Inequality in Zimbabwe: Factors that Impede the Advancement of Women into Leadership Positions in Primary Schools', South African Journal of Education, 29: 235-51. https://doi.org/10.15700/saje.v29n2a259

Chen, Y., Gupta, A. \& Hoshower, L. (2006), 'Factors that Motivate Business Faculty to Conduct Research: An Expectancy Theory Analysis', Journal of Education for Business, 81, 179-89. https://doi.org/10.3200/JOEB.81.4.179-189

Choruma, A. (2019), 'Gender Diversity in Leadership Needed', The Sunday Mail, Zimbabwe.

Cohn, E.G., Farrington, D.P. \& Iratzoqui, A. (2014), Most-cited Scholars in Criminology and Criminal Justice, 1986-2010 (Cham, Springer). https://doi.org/10.1007/978-3-319-01222-3

Collier, A. \& Gray, B. (2010), The Commercialization of University Innovations-A Qualitative Analysis of the New Zealand Situation (Otago, Centre for Entrepreneurship, School of Business, University of Otago).

Commission for University Education (Kenya) (2018), State of University Education in Kenya. Quality: The Agenda. https://www.researchgate.net/profile/Eusebius-Mukhwana/publication/307906466_ State_of_University_Education_in_Kenya/links/57d149a508ae0c0081e00e10/State-of-UniversityEducation-in-Kenya.pdf

Davidson, M. \& Burke, R. (2004), Women in Management World-wide: Facts, Figures and Analysis. (Aldershot, Ashgate).

Fahmy, C. \& Young, J.T.N. (2017), 'Gender Inequality and Knowledge Production in Criminology and Criminal Justice', Journal of Criminal Justice Education, 28(2): 285-305. https://doi.org/10.1080/10511253.2016.1233346

Fathima F.N., Awor P., Yen Y-C., Gnanaselvam N.A. \& Zakham F. (2020), 'Challenges and Coping Strategies Faced by Female Scientists-A Multicentric Cross Sectional Study', PLoS ONE, 15(9): e0238635. https://doi.org/10.1371/journal.pone.0238635

Fisher, B.S., Vander Ven, T.M., Cobane, C.T., Cullen, F.T. \& Williams, N. (1998), 'Trends in Multipleauthored Articles in Criminology and Criminal Justice: A Comparative Analysis', Journal of Criminal Justice Education, 9: 19-38. https://doi.org/10.1080/10511259800084161

Garwe, E.C. (2015), 'Obstacles to Research and Publication in Zimbabwean Higher Education Institutions: A Case Study of the Research and Intellectual Expo', International Research in Education, 3: 1. https://doi.org/10.5296/ire.v3i1.7009

Government of Zimbabwe (2017), Ministry of Higher and Tertiary Education, Innovation, Science and Technology Development Annual Report (Harare, Government of Zimbabwe).

Government of Zimbabwe (2018), Ministry of Primary and Secondary Education Annual Report (Harare, Government of Zimbabwe).

Guzura, P. (2012), 'Gender Equality in Institutions of Higher Learning in Zimbabwe: A Case of Midlands State University's Experience with Female Advancement, 2004-2007', Global South SEPHIS e-magazine, 8: 2.

Hassan, M. (2001), 'Can Science Save Africa?', Science, 292: 609. https://doi.org/10.1126/science.292.5522.1609

Houweling, E.V., Christie, M.E, \& Rahim, A.A. (2018), 'Women's Access and Experience in Higher Education Agricultural Programs in Africa', Gender and Education, 32(4): 486-504. https://doi.org/10.1080/09540253.2018.1495832 
Kolmar, W. \& Bartowski, F. (2005), 'The Changing Woman' (Navajo Origin Myth). Feminist Theory: A Reader, 2nd edn (New York, McGraw-Hill).

Mama, A. \& Barnes, T. (2007), 'Editorial: Rethinking Universities', Feminist Africa, 8: 1-7.

Moletsane, R. \& Reddy, V. (2008), Report: An Assessment of the Participation of Women in Set Industry for Department of Science and Technology (Pretoria, Human Sciences Research Council).

Morley, L. (2005), 'Gender Equity in Commonwealth Higher Education', Women's Studies International Forum, 28: 209-21. https://doi.org/10.1016/j.wsif.2005.04.008

Morley, L. (2010), 'Gender Mainstreaming: Myths and Measurement in Higher Education in Ghana and Tanzania', Compare: A Journal of Comparative Education, 40: 533-50. https://doi.org/10.1080/03057925.2010.490377

Mowery, D.C. \& Sampat, B.N. (2007), Universities in National Innovation Systems (Oxford, Oxford University Press). https://www.oxfordhandbooks.com/view/10.1093/oxfordhb/9780199286805 001.0001/oxfordhb-9780199286805-e-8

Munando, E. (2017), Building the Base: Empowering Female Higher Education Students in Zimbabwe by Female Students (Network Trust (Zimbabwe); Paris, UNESCO).

National Commission for Science, Technology and Innovation (2014), Strategic Plan 2018-2022 (Nairobi, NACOSTI). https://www.nacosti.go.ke/images/docs/2019/NACOSTI\%20STRATEGIC $\% 20$ PLAN.pdf

Nketiah, R. (2019), What we Know: The Role of Knowledge Production in Owning our Narratives as African Feminists (Accra, African Women's Development Fund). https://awdf.org/whatwe-know-the-role-of-knowledge-production-in-owning-our-narratives-as-african-feminists/

O’Connor P., Carvalho T., Vabø A. \& Cardoso S. (2015), 'Gender in Higher Education: A Critical Review’, in J. Huisman, H. de Boer, D.D. Dill \& M. Souto-Otero (eds) The Palgrave International Handbook of Higher Education Policy and Governance (London, Palgrave Macmillan). https://doi.org/10.1007/978-1-137-45617-5_30

Odhiambo, G. (2011), 'Women and Higher Education Leadership in Kenya: A Critical Analysis', Journal of Higher Education Policy and Management, 33: 667-78.

https://doi.org/10.1080/1360080X.2011.621192

Oduwaye, R.O., Owolabi, H.O., Onasanga, S.A. \& Shehu, R.A. (2010), 'Research Dissemination, Utilization and Commercialization by Lecturers of a Nigerian University: Case Study of University of Ilorin', Journal of Educational Review, 3: 2.

Ogunwusi, A.A. \& Ibrahim H.D. (2014), 'Promoting Industrialization through Commercialization of Innovation in Nigeria', Industrial Engineering Letters, 4(7): 17-29.

Papadópulos, J. \& Radakovich, R. (2005), Estudio comparado de Educación Superior y género en América Latina y el Caribe [Comparative study of higher education and gender in Latin America and the Caribbean]. http://www.cned.cl/public/Secciones/SeccionRevistaCalidad/doc/52/CSE_res ... [Accessed 6 June 2020].

Pop, D. (2016), 'Patriarchal Discourses and Anti-feminine Attitudes in Romanian Political and Media Cultures', Caietele Echinox, 30.

Prozesky, H. \& Mouton, J. (2019), 'A Gender Perspective on Career Challenges Experienced by African Scientists', South African Journal of Science, 115: 3-4. https://doi.org/10.17159/sajs.2019/5515

Rice, S.K., Terry, K.J., Miller, H.V. \& Ackerman, A.R. (2007), 'Research Trajectories of Female Scholars in Criminology and Criminal Justice', Journal of Criminal Justice Education, 18: 360-84. https://doi.org/10.1080/10511250701705305

Ronning, A.H. (2000), 'Gender, Culture and Power-sharing in Academia', in M.-L.Kearney (ed.) Women, Power and Academy: From Rhetoric to Reality (Paris, UNESCO).

Sachs, J. (2005), The End of Poverty: Economic Possibilities for Our Time (London, Penguin Press).

Sanday, P.R. (2002), Women at the Center, Life in a Modern Patriarchy (Ithaca, NY, Cornell University Press). 
Sax, L.J., Hagedorn, L.S., Arredondo, M. \& Dicrisi III, F.A. (2002), 'Faculty Research Productivity: Exploring the Role of Gender and Family-related Factors', Research in Higher Education, 43: 423-46. https://doi.org/10.1023/A:1015575616285

Schemm, Y. (2013), 'Africa Doubles Research Output over Past Decade, Moves Towards a Knowledgebased Economy', International Centre for the Study of Research (Elsevier).

Snell, C., Sorensen, J., Rodriguez, J.J. \& Kuanliang, A. (2009), 'Gender Differences in Research Productivity among Criminal Justice and Criminology Scholars', Journal of Criminal Justice, 37: 288-95. https://doi.org/10.1016/j.jcrimjus.2009.04.009

Stewart, K.A. (2006), 'Can a Human Rights Framework Improve Biomedical and Social Scientific HIV/ AIDS Research for African Women?', Human Rights Review, 7(2): 130-6. https://doi.org/10.1007/s12142-006-1034-3

Tantiyaswasdikul, K. (2013), 'Technology Transfer for Commercialization in Japanese University: A Review of the Literature', Japanese Studies Journal. http://www.asia.tu.ac.th/journal/J_Studies30_1/70-85.pdf

UN (United Nations) (2015), Universal Declaration of Human Rights (New York, United Nations).

World Bank (2005), Meeting the Challenge of Africa's Development: A World Bank Group Action Plan (Washington, DC, World Bank).

Zimbabwe National Statistics Agency (2019), 'Understanding Gender Equality in Zimbabwe: Women and Men in Zimbabwe Report' (Harare, Zimbabwe National Statistics Agency).

\section{Notes about the authors}

Promise Zvavahera, BBM \& IT (Hons), MBA, Msc in Development Studies, PhD, Deputy Registrar Human Resources \& Administration and Human Resources and Lecturer at Africa University, Zimbabwe. His areas of research are motivation and productivity, corporate governance, works ethics, and artificial intelligence. promisezvavahera59@gmail.com

Mercy Dikito Wachtmeister, PhD; MA Development Studies; Post Grad ResearchUK - Consultant in Gender and Social inclusion, integrated water resources management (IWRM), transboundary water management; water and sanitation. mdikitowachtmeister@gmail.com

Sheppard Pasipanodya, Bsc (Hons) Information Systems, Msc Information Systems Management, Dean Faculty of Commerce Bachelor of Business Management, Lecturer at Catholic University of Zimbabwe.

spasipanodya@cuz.ac.zw

Natasha Salome Mwenda, BSc Agriculture (Agric. Extension), MA in Development Studies, Programme Manager at WaterAid-Malawi.

natamwenda@gmail.com 
George Okumu Achar, B.Th., M.Div. in Theological Studies, PhD in Religion, Lecturer in the Institute of Theology and Religious Studies at Africa University, Zimbabwe.

gokumachar@gmail.com

To cite the article: Promise Zvavahera, Mercy Dikito-Wachtmeister, Sheppard Pasipanodya, Natasha Salome Mwenda and George Okumu Achar (2021), 'Gender and knowledge production in institutions of higher learning: an African context', Journal of the British Academy, 9(s1): 217-241.

DOI https://doi.org/10.5871/jba/009s1.217

Journal of the British Academy (ISSN 2052-7217) is published by

The British Academy, 10-11 Carlton House Terrace, London, SW1Y 5AH

www.thebritishacademy.ac.uk 
